\title{
Anatomy and physiology for nursing students: is problem-based learning effective?
}

\author{
E' efficace il metodo del problem-based learning per l'insegnamento dell' Anatomia e Fisiologia \\ agli studenti Infermieri?
}

\author{
Lidia Mayner $^{1}$
}

David Gillham ${ }^{2}$

Julita Sansoni ${ }^{3}$

\begin{abstract}
This study investigated whether problem-based learning (PBL) was an effective strategy for nursing students learning anatomy and physiology. Anatomy and physiology are subject areas that have posed long standing difficulty for nursing students. Since anatomy and physiology underpin clinical decision making it is important that nursing students are able to understand and retain this knowledge and apply it to practice. Problem-based learning offers potential advantages for teaching anatomy and physiology as clinical cases can provide the impetus for student problem solving. This project trialled a simple PBL scenario and investigated students' response to the task of problem solving in a laboratory setting adapted to simulate a hospital ward. The study found students learn better, retain the knowledge and merge theory with simulated practice when a PBL teaching mode is used. While PBL was effective, blended, web based and hybrid PBL models warrant investigation.
\end{abstract}

Key words: problem-based learning, student motivation, deep learning, anatomy and physiology, nursing

RIASSUNTO

Questo studio vuole investigare se il metodo del problem-based learning (PBL) può essere utilizzato nell'insegnamento della anatomia e fisiologia agli studenti Infermieri visto che spesso hanno difficoltà in queste discipline. E' importante che gli studenti comprendano e imparino bene i contenuti di queste materie poiché queste sono la base per prendere decisioni cliniche. Il metodo del PBL offre possibili vantaggi nell'insegnamento dell'anatomia e della fisiologia e fornisce agli studenti l' impulso di come portare alla soluzione dei problemi clinici. Questo studio ha usato uno scenario semplice utilizzando il metodo del PBL per valutare le risposte degli studenti e analizzare come risolvevano $\mathrm{i}$ problemi clinici in situazioni simulate di laboratorio, simili alla realtà della corsia. I risultati di questo studio evidenziano che quando viene usato il metodo del PBL nella docenza. Gli studenti imparano meglio, ritengono più informazioni e possono meglio comprendere la teoria per svilupparla nella simulazione della pratica. Il metodo del PBL è stato efficace ma devono essere studiati ed applicati anche altri modelli come il metodo blended, il metodo basato sullo web e i metodi ibridi.

Parole chiave: problem-based learning, motivazione di studenti, deep learning, anatomia e fisiologia, infermieristica

\section{INTRODUCTION}

$\mathrm{T}$ he accurate application of knowledge from anatomy and physiology to clinical problem solving is a crucial component of nursing practice. Poor understanding or recall of anatomy and physiology or the inability to apply theory to practice may result in serious adverse outcomes for patients and contribute to detrimental public perception of the nursing profession. However, it is apparent that nursing students consistently have difficulty understanding and retaining information on anatomy and physiology and struggle with the application of this content in clinical practice (Boelen et al., 2009; White et al., 2012). Since these areas underpin clinical practice and decision making

1 PhD RN, School of Nursing and Midwifery, Flinders University,Adelaide, South Australia, Australia. E-mail: lidia.mayner@flinders.edu.au

2 PhD RN, School of Nursing and Midwifery, Flinders University,Adelaide, South Australia, Australia.

3 EdDr, RN, Unit of Nursing Research, Public Health and Infectious

DIseases, Sapienza Università di Roma
(White et al., 2012) it is important that nursing students are able to understand and retain this knowledge and apply it to practice. Teaching anatomy and physiology has traditionally used lectures, practicals and tutorials with theory and practice taught separately in nursing programs. This traditional approach to teaching anatomy and physiology remains widespread. However, many nursing students perform badly in bioscience related subjects. While students claim to like and be interested in these subjects they find them very difficult.

McMaster University in Canada and specifically Howard Barrows are credited with founding the use of problem based learning (PBL) as applied to medicine and health sciences education. Barrows et al. (1980) explained that problem-based learning is ideally suited to the education of health professionals as it simultaneously develops knowledge, reasoning and study skills by structuring the cognitive process of clinical reasoning into the formal curriculum. To summarise, Barrows et al. (1980) described clinical reasoning as the cognitive process of identifying cues from case information and 


\begin{tabular}{|c|l|}
\hline Stage one & $\begin{array}{l}\text { Susan, a 25-year-old female was mowing the lawn when she experienced difficulty in breathing. Her friend helped her inside } \\
\text { the house but Susan looked very flushed and since she continued to have great difficulty in breathing her friend phoned an } \\
\text { ambulance. Susan was taken to the emergency department in a nearby public hospital. }\end{array}$ \\
\hline Stage two & $\begin{array}{l}\text { Susan' S observations were BP: } 130 / 80 \mathrm{~mm} \mathrm{Hg;} \mathrm{PaO2:} 80 \mathrm{~mm} \mathrm{Hg;} \mathrm{PaCO2:} 50 \mathrm{~mm} \mathrm{Hg;} \mathrm{respiratory} \mathrm{rate} \mathrm{was} 30 \text { beats per } \\
\text { minute and Susan had difficulty in talking in full sentences. }\end{array}$ \\
\hline Stage three & $\begin{array}{l}\text { The registrar gave Ventolin to Susan who soon recovered but remained at the hospital overnight. Susan was discharged } \\
\text { the next morning. }\end{array}$ \\
\hline
\end{tabular}

Table 1. Respiratory system case-based scenario

assessment evidence and then clustering the cues in a meaningful way to formulate hypotheses. Barrows (1996), reported on the evolutionary development of PBL, defined PBL as incorporating the key elements of: "learning is student centred; involves teaching with small groups; facilitators guide these groups; new information is acquired through self-directed learning; problems are a vehicle for the development of dinical problem-solving skills."

Neville, (2009), reported the findings of recent systematic reviews addressing PBL in medical education highlighting inconsistencies in the findings, attributing these to the wide range of descriptions of PBL and the inconsistent use of outcome measures. Neville (2009) while acknowledging the founding work of Barrows (1996) concluded that PBL is effective particularly when combined with the prior development of understanding of basic terms and concepts.

In nursing specifically, Alavi (1995) played an important role in development of PBL highlighting that as a practice-based profession that incorporates a team approach, teaching should therefore reflect the complexities of functioning within a group environment and include problem-solving with learning packages developed from real-life situations. Alavi agreed that problem-based learning is ideally suited to professional health sciences because a structured, problem-based learning package integrates practice with theory and promotes a sound understanding of the area of study. In parallel to developments in medicine, more recent reports of PBL in nursing advocate hybrid approaches, with more structured student support than the pioneering PBL work (Goopy et al., 2001; Lee, 2006)

This paper reports on our attempt to apply a different mode of teaching on a voluntary trial basis for just one area of anatomy and physiology. By using the problem based learning (PBL) approach we hoped to link anatomy and physiology to authentic cases, thereby explicitly emphasising the relevance of science content to clinical practice while integrating theory and practice in a manner which parallels workplace decision making. We anticipated this approach would appeal to the learning styles of the diverse nursing student group as simulated patient welfare was central to the learning process.

\section{METHODS}

\section{Participants}

Sample selection: at the commencement of an anatomy and physiology lecture first year students (the cohort consisted of both nursing and health sciences students) were asked if they would like to volunteer for a trial PBL session. Twenty six students volunteered, only their first name was recorded for purposes of timetabling their session. Twenty four were nursing students and two were health sciences students. Six identical sessions were presented; each session had no more than six students and lasted 50 minutes, which was then followed by a 20 minute interview. Each student attended only one of the six sessions.

\section{Materials and Procedure}

Several days prior to the trial PBL week each student received a learning package consisting of instructions to students, details of what theory would be covered by the session and details on how the PBL sessions would run if adopted as a method of teaching. The objectives of the trial respiratory PBL session were detailed, followed by the case study that was divided into three stages (.Table 1 ). In preparation for the PBL session students were asked to read the case study then answer a few general and specific questions. The package also included pre-reading from their textbook covering the anatomy and some physiology of the respiratory system.

The six sessions were held in the anatomy laboratory where there were models on several tables and charts in clear view related to the respiratory system. The senior lecturer in charge of the topic presented the case study PBL sessions. The interviewer, a senior clinical nurse, was responsible for all 6 interview sessions with the students.

The interview after the PBL session was held in a room adjoining the anatomy laboratory. The interviewer recorded in writing the responses to the interviews. The questions asked in the interview are listed in Table 2.

These were designed to evaluate students qualitatively on subject knowledge/content, understanding and knowledge retention as well as their preferences about the trial PBL teaching method. Each group's responses to the interview were analysed using the framework analysis method described by Ward et al. (2013). The pre-set questions are listed in Table 2 and themes derived from the interviews are shown in Table 3.

\section{Ethics approval}

Prior to commencing the trial PBL session, ethics approval was sought from the chairperson of the Social and Behavioural Ethics Committee at the University and each student signed a consent form. This study and publication has complied with the directions of the committee requiring that the anonymity of students be preserved at all times. 


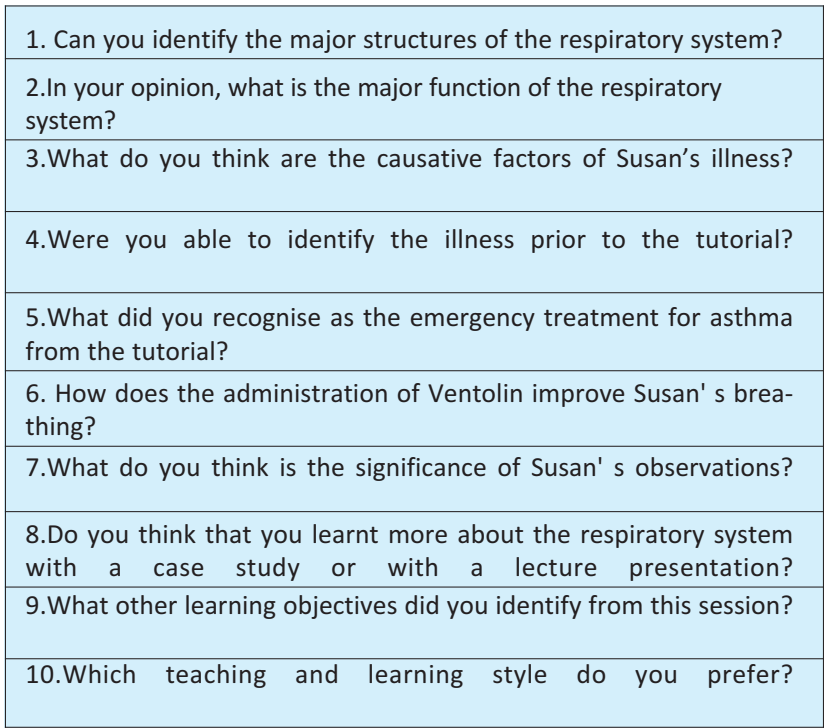

Table 2. Questions used during the interview

\begin{tabular}{|c|c|}
\hline Themes & Summary of students' responses \\
\hline $\begin{array}{l}\text { Subject knowledge/ } \\
\text { content }\end{array}$ & $\begin{array}{l}\text { Overall, all had good understanding of the ana- } \\
\text { tomy and function of the respiratory system. }\end{array}$ \\
\hline $\begin{array}{l}\text { Understanding of } \\
\text { subject }\end{array}$ & $\begin{array}{l}\text { All students showed interest and asked que- } \\
\text { stions about what they did not understand prior } \\
\text { to that PBL session. At the completion all stu- } \\
\text { dents stated they felt comfortable with their } \\
\text { understanding of the subject matter. }\end{array}$ \\
\hline $\begin{array}{l}\text { Retention of } \\
\text { knowledge }\end{array}$ & $\begin{array}{c}\text { During the interview all students participated in } \\
\text { a review of the subject material covered in the } \\
\text { PBL session, demonstrating retention } \\
\text { of knowledge. }\end{array}$ \\
\hline $\begin{array}{l}\text { Willingness to } \\
\text { pursue own learning } \\
\text { objectives }\end{array}$ & $\begin{array}{c}\text { When invited by the interviewer, all students } \\
\text { were willing to share the learning objectives } \\
\text { with the group. }\end{array}$ \\
\hline $\begin{array}{l}\text { Willingness to fur- } \\
\text { ther research topic }\end{array}$ & $\begin{array}{c}\text { Several indicated an interest to further research } \\
\text { the physiology of asthma. }\end{array}$ \\
\hline $\begin{array}{l}\text { Students' ability to } \\
\text { relate theory to } \\
\text { practice }\end{array}$ & $\begin{array}{l}\text { All students appreciated the connection betwe- } \\
\text { en theory and practice making the subject con- } \\
\text { tent meaningful and relevant. }\end{array}$ \\
\hline $\begin{array}{l}\text { Motivation for } \\
\text { learning }\end{array}$ & $\begin{array}{l}\text { All students appeared very interested in the } \\
\text { subject matter as well as the pathophysiology } \\
\text { of the case. All students had completed the } \\
\text { question in the learning packages. }\end{array}$ \\
\hline $\begin{array}{l}\text { Motivation for } \\
\text { discussion }\end{array}$ & $\begin{array}{l}\text { In each session students were very willing to } \\
\text { discuss their ideas and thoughts about the case } \\
\text { study. Small group work encouraged group } \\
\text { discussion as students found it to be a more } \\
\text { relaxed environment for learning. }\end{array}$ \\
\hline $\begin{array}{l}\text { Ability to work in a } \\
\text { team }\end{array}$ & $\begin{array}{l}\text { Students co-operated well within each group } \\
\text { and supported each other's hypotheses regar- } \\
\text { ding the case study. }\end{array}$ \\
\hline $\begin{array}{l}\text { Simulated expe- } \\
\text { riential learning }\end{array}$ & $\begin{array}{l}\text { Students welcomed the opportunity to connect } \\
\text { the theory with the real ward situation. }\end{array}$ \\
\hline
\end{tabular}

Table 3 Summary of results of students' knowledge of the respiratory system from the interviews.

\section{RESULTS}

In this project there are two foci of findings, one is based on the answers given by students to the questions regarding their knowledge about the respi- ratory system and the other focus is the student perception of the case-based scenario, PBL style of teaching and learning. Table 3 below, shows a summary the themes associated with the interview questions and a corresponding summary of the students' responses outlining the students' knowledge about the respiratory system during the PBL session as assessed by the senior lecturer and the interviewer. The first three themes relate to students' knowledge and the remainder relate to students' perception of PBL.

Twenty five of the twenty six students participating in this study indicated a preference for a PBL format. They commented that a case study was a more meaningful application of their knowledge base as it related to a real situation and was relevant to their professional development. Students also indicated a preference for smaller group work because it allowed them to ask questions and to participate in discussion by providing a more comfortable and relaxed environment as compared to a lecture. This is supported by the comments from the participating students which are listed according to the key elements from the work of Barrows (1996).

Student comments regarding this aspect of PBL style of learning were: ' brings purpose to learning'; ' puts it into perspective'; ' it's better to see it as a model then you remember it'; ' practicals could be done at home, I would rather do this'; 'you can pick up from other people areas that you don't understand'.

The interview responses supported that the volunteers found the PBL approach stimulating because it challenged them to pursue new learning objectives of their own. Bioscience has always been presented traditionally with lectures in this School, this was the first time students had an opportunity to compare a different mode of teaching. The students' comments from the interviews were as follows. They felt that: ' more opportunity for feedback'; ' I like to be able to ask questions'; ' I like small group tutorials because they are more interactive and everyone gets involved'; ' I like small groups as you can discuss and talk with the tutor about things you don't know'.

In the students' own words specifically about lectures: ' you have to take in so much at a lecture that you can't understand it all'; ' lectures are too detailed to absorb the necessary information so you learn more than you need and you don't take it all in'. Students commented that they felt empowered to identify their own learning issues for further research and to reflect on their learning. This finding is supported by Siu, Laschinger, and Vingilis (2005). The students enjoyed connecting the theory with a' real' event as indicated by the following comments: ' this relates to reality'; ' made more sense as it relates to a real case'; ' connects the theory with a real-life situation'. Overall, the students enjoyed the casebased session and were enthusiastic in learning the work. 


\section{DISCUSSION}

This pilot study was undertaken to gauge how an alternative method for teaching bioscience, namely anatomy and physiology would be received by the students in this school. All students except one from health science preferred the PBL method of teaching to the more traditional weekly lectures and tutorials or practical sessions. All students showed good understanding of the anatomy and physiology of the respiratory system and all, except one of the Health Sciences students, enjoyed the PBL session and stated a preference for this type of teaching. This observation is supported by Barrows (1996) original work and later by others (Hwang et al., 2006; Kocaman et al., 2009; Lee, 2006; Thistlethwaite et al., 2012) that small groups and case scenarios will provide motivation for student learning. Albeit the many papers about PBL style of teaching none have pointed out that students need to be in a practice based allied health profession to appreciate the PBL style of learning. The Health Science student who was not in favour of this type of learning was not in a practice based environment and would not have been able to connect the scenario with a real life situation.

Communication, team work and critical thinking skills. From our observations with this trial and reflecting on the literature discussed, there seemed to be several positive features that would justify expanding the role of PBL in nursing education. Problem-based learning uses real or simulated case scenarios and so is close to experiential learning. It creates the feel of a real situation so that students engage with the case if they are learning from their own experience developing critical thinking skills as suggested by other researchers (Hodges, 2011; Magnussen et al., 2000; Oja, 2011). Problem-based learning also enables students to have a planned experience of cooperation, communication (Utsun, 2006) and teamwork through small group work. This is excellent preparation for working in a health care setting where the team approach is implemented. Problem-based learning encourages students to actively engage with their learning through questioning, discussing and researching the problem in hand. These skills prepare students to be lifelong learners (Kocaman et al., 2009). Problem-based learning also encourages reflection. Students reflect back over the case, reviewing and analysing what they have learned. In this way they are integrating what has been learned into their knowledge base and remembering it for future reference.

Deep learning and motivation theme. Findings of this study support evaluative literature related to PBL and deep learning as students valued the connection between theory and practice and showed improved understanding and retention of content. This is consistent with the deep learning associated with PBL reported previously (Abraham et al., 2008; Fyrenius et al., 2007; Nayak et al., 2006; Tiwari et al., 2006). Similarly this study found PBL enhanced motivation, as reported by others (Hwang et al., 2006; Kocaman et al., 2009; Lee, 2006; Taradi et al., 2005).

The case-based scenario and PBL. The scenario was a simple one but broken up in three stages so that students could work through each stage and build on their knowledge. It has been pointed out that an overly complex scenario would hinder learning (Berkson, 1993 cited in Neville, 2009). Although the scenario was simple, it touched not only on elements of anatomy and physiology but extended to pathophysiology, pharmacology and clinical nursing skills. This combination helped students integrate the bioscience theory into practice. Students were encouraged to consult the textbook given the directions from the case-based scenario. This is an encouraging outcome since most nursing students are reticent in using the textbook due to its complexity and volume of information. Students were clearly in favour of the PBL sessions as opposed to lectures given their comments that too much information is given, too fast during a lecture period. Selfdirected learning allowed students to read and learn at their own pace.

Future implications. Blended learning, cases and the web. This pilot study reported the initial implementation of a problem based learning trial for teaching anatomy and physiology in an Australian nursing school. Concurrent to this development has been a large scale move in the nursing school to a blended teaching and learning approach with substantial emphasis on web-based learning. While our study has been of limited scope and resource intensive, the findings and consideration of related literature suggest the combination of traditional teaching of basic concepts, case based presentation, semi-structured, self-directed web based problem solving, followed by face to face facilitated group work may provide an integrated approach that captures the theory-practice links of PBL and utilises the quality and range of web resources, while still providing the basic conceptual understanding required to enable deep integrated learning. Given the recent emphasis directed to blended learning (Nayak et al., 2006; Taradi et al., 2005; White et al., 2012), and hybrid approaches to PBL that develop basic concepts (Neville, 2009), consideration of the findings of this study in the context of broader literature suggest that the combination of traditional approaches, web-based learning and face to face PBL may soon be at the forefront of nurse education.

Limitation of the study. The study was limited by self-selection to the study group and the potential influence of the enthusiasm of the facilitator, a senior lecturer and coordinator of the topic. While the interviews were not conducted by the facilitator, the results may still reflect the skill level and enthusiasm of the facilitator, who in this case was a senior lecturer with a science background. Mete et al. (2008) found that tutor behaviour was a major influencing factor on the successful delivery of PBL, highlighting the need for staff development of PBL facilitators. 


\section{SIGNIFICANCE OF THIS STUDY}

This study found overwhelming support for the use of case based scenario using a PBL approach to teach anatomy and physiology to nursing students. Teaching using a PBL style motivated students to learn and critical think through all aspects of the scenario in a self-directed student centred environment. They practiced and developed their communication and team work skills in an area, anatomy and physiology that was usually dominated by lecturers or tutors presenting the information. Given the emphasis in recent literature on more structured approaches to PBL, a future strategy will be a blended approach incorporating case based learning and the use of high quality web resources for anatomy and physiology.

\section{REFERENCES}

Abraham, R.R., Vinod, P., Kamath, M.G., Asha, K., \& Ramnarayan, K. (2008). Learning approaches of undergraduate medical students to physiology in a nonPBL- and partially PBL-oriented curriculum. Advances in Physiology Education, 32, 35-37.

Alavi, C. (1995). Helping teachers to help students learn. In C. Alavi, (Ed.), Problem-based learning in a health sciences curriculum, (pp. 116-125). London: Routledge.)

Barrow, E.J., Lyte, G., \& Butterworth, T. (2002). An evaluation of problem-based learning in a nursing theory and practice module. Nurse Education in Practice, 2, 55-62.

Barrows, H.S., \& Tamblyn, R.M. (1980). Problem-based learning An Approach to medical education. New York:Springer.

Barrows, H.S. (1996). Problem-based learning in medicine and beyond: A brief overview. New Directions for Teaching and Learning, 1996, 3-12.

Boelen, M.G., \& Kenny, A. (2009). Supporting enrolled nurse conversion - The impact of a compulsory bridging program. Nurse Education Today, 29, 533-537.

Fyrenius, A., Silen, C., \& Wirell, S. (2007). Students' conceptions of underlying principles in medical physiology: an interview study of medical students' understanding in a PBL curriculum. Advances in Physiology Education, 3, 364-369.

Hodges, H.F. (2011). Preparing New Nurses with Complexity Science and Problem-Based Learning. Journal of Nursing Education, 50, 7-13.

Hwang, S.Y,. \& Kim, M.J. (2006). A comparison of problem-based learning and lecture-based learning in an adult health nursing course. Nurse Education Today, 26, 315-321.

Kocaman, G., Dicle, A., \& Ugur, A. (2009). A Longitudinal Analysis of the Self-Directed Learning Readiness Level of Nursing Students Enrolled in a Problem-Based Curriculum. Journal of Nursing Education, 48, 286-290.

Lee, S. (2006). The Effect of Problem-Based Learning on Improving Learning Abilities of BSN Students in Taiwan.
International Nursing Research Congress. Data accessed March 19, 2012 http://hdl.handle.net/ 10755/152484

Goopy SE, Sansoni J. (2001). Problem-based learning in nursing training: liberation or confinement?].Prof Inferm.;54(2):77-84

Magnussen, L., Ishida, D., \& Itano, J. (2000). The impact of the use of inquiry-based learning as a teaching methodology on the development of critical thinking. Journal of Nursing Education, 39, 360-364. http://search.proquest. com/docview/203903713? accountid=10910. Data accessed September 10, 2012

Mete, S., \& Sari, H.Y. (2008). Nursing students' expectations from tutors in PBL and effects of tutors' behaviour on nursing students. Nurse Education Today, 28, 434-442.

Nayak, S., Ramnarayan, K., Somayaji, N., \& Bairy, KL. (2006). Teaching anatomy in a problem-based learning (PBL) curriculum. Neuroanatomy, 5, 2-3. http://www.neuroanatomy.org/ 2006/002_003.pdf. Data accessed August 30, 2012

Neville, A.J. (2009). Problem-Based Learning and Medical Education Forty Years On. Medical Principles and Practice, 18, 1-9.

Oja, K.J. (2011). Using Problem-Based Learning in the Clinical Setting to Improve Nursing Students' Critical Thinking: An Evidence Review. Journal of Nursing Education, 50, 145-151.

Siu, H.M., Laschinger, H.K.S., \& Vingilis, E. (2005). The Effect of Problem-Based Learning on Nursing Students' Perceptions of Empowerment. Journal of Nursing Education, 44, 459-469. http://search.proquest.com/ docview/203932652?accountid=10910. Data accessed April 20, 2012

Taradi, S.K., Taradi, M., Radic, K., \& Pokrajac, N. (2005). Blending problem-based learning with Web technology positively impacts student learning outcomes in acid-base physiology. Advances in Physiology Education, 29, 35-39.

Thistlethwaite, J.E., Davies, D., Ekeocha, S., Kidd, J.M., MacDougall, C., Matthews, P., Purkis, J., \& Clay, D. (2012). The effectiveness of case-based learning in health professional education. A BEME systematic review: BEME Guide No. 23. Medical Teacher, 34, e421-e444.

Tiwari, A., Chan, S., Wong, E., Wong, D., Chui, C., Wong, A., \& Patil, N. (2006). The effect of problem-based learning on students' approaches to learning in the context of clinical nursing education. Nurse Education Today, 26, 430-438.

Tufts, M.A., \& Higgins-Opitz, S.B. (2009). What makes the learning of physiology in a PBL medical curriculum challenging? Student perceptions. Advances in Physiology Education, 33, 187-195.

Utsun, B. (2006). Communication Skills Training as Part of a Problem-Based Learning Curriculum. Journal of Nursing Education, 45, 421-424.

White, S., \& Sykes, A. (2012). Evaluation of a Blended Learning Approach Used in an Anatomy and Physiology Module for Pre-registration Healthcare Students, In The Fourth International Conference on Mobile, Hybrid, and Online Learning, IARIA, pp. 1-9. http://www.thinkmind.org/index.php? view=article\& articleid=elml_2012_1_10_50027. Data accessed November 5,2012 